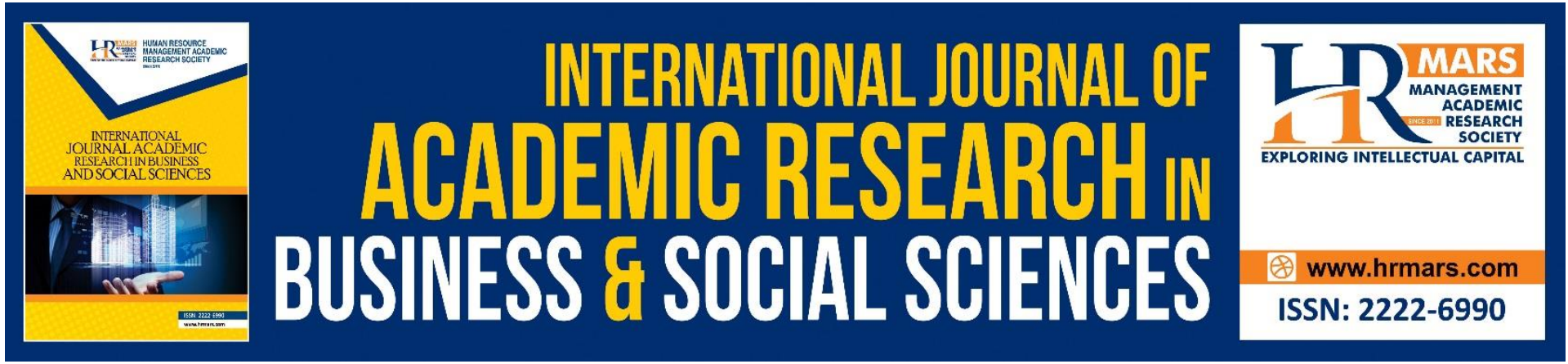

\title{
The Application of Aristotle's Rhetorical Theory to Evaluate Fresh Graduates' Job Interview Performance
}

Isai Amutan Krishnan, Kausalya Muthutamilselvan, Mohammad Nor Afandi bin Ibrahim, Geraldine De Mello, Selvajothi Ramalingam, Elanttamil Maruthai, Nalini Arumugam

To Link this Article: http://dx.doi.org/10.6007/IJARBSS/v11-i8/10793

DOI:10.6007/IJARBSS/v11-i8/10793

Received: 08 June 2021, Revised: 16 July 2021, Accepted: 30 July 2021

Published Online: 20 August 2021

In-Text Citation: (Krishnan et al., 2021)

To Cite this Article: Krishnan, I. A., Muthutamilselvan, K., Ibrahim, M. N. A. bin, Mello, G. De, Ramalingam, S., Maruthai, E., \& Arumugam, N. (2021). The Application of Aristotle's Rhetorical Theory to Evaluate Fresh Graduates' Job Interview Performance. International Journal of Academic Research in Business and Social Sciences, 11(8), 1009-1028.

\section{Copyright: @ 2021 The Author(s)}

Published by Human Resource Management Academic Research Society (www.hrmars.com)

This article is published under the Creative Commons Attribution (CC BY 4.0) license. Anyone may reproduce, distribute, translate and create derivative works of this article (for both commercial and non-commercial purposes), subject to full attribution to the original publication and authors. The full terms of this license may be seen at: http://creativecommons.org/licences/by/4.0/legalcode

Vol. 11, No. 8, 2021, Pg. 1009 - 1028

Full Terms \& Conditions of access and use can be found at http://hrmars.com/index.php/pages/detail/publication-ethics 


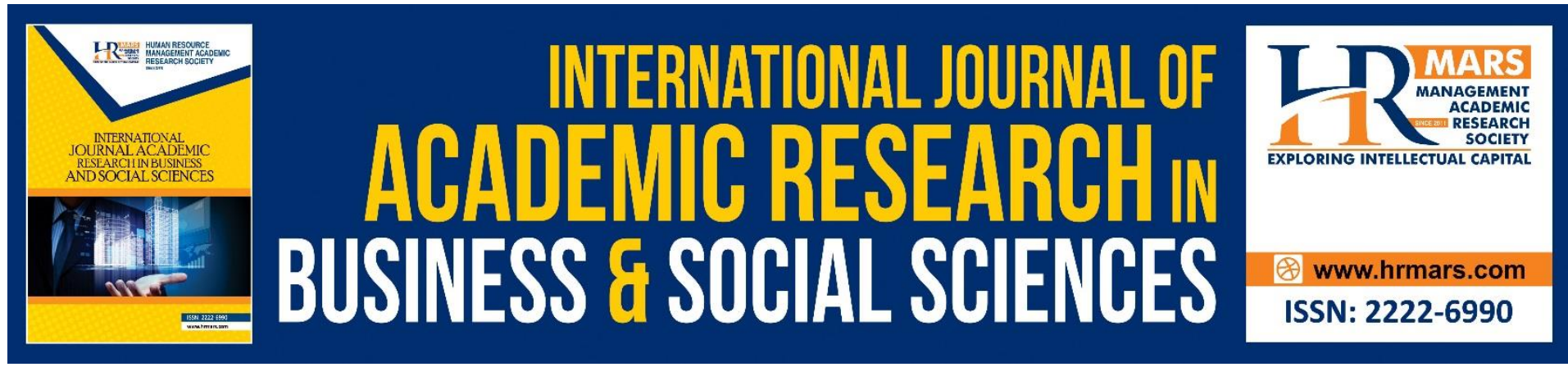

\section{The Application of Aristotle's Rhetorical Theory to Evaluate Fresh Graduates' Job Interview Performance}

Isai Amutan Krishnan ${ }^{1}$, Kausalya Muthutamilselvan², Mohammad Nor Afandi bin Ibrahim³ ${ }^{3}$, Geraldine De Mello ${ }^{4}$, Selvajothi Ramalingam ${ }^{5}$, Elanttamil Maruthai ${ }^{6}$, Nalini Arumugam ${ }^{7}$

${ }^{1,2}$ Faculty of Languages and Linguistics, University of Malaya, ${ }^{3,4}$ Academy of Language Studies, Universiti Teknologi MARA Melaka, Malaysia, ,5, 6 Department of Malaysian Languages and Applied Linguistics, Faculty of Languages \& Linguistics, University of Malaya, ${ }^{7}$ Academy of Language Studies, Universiti Teknologi MARA Shah Alam, Selangor, Malaysia

\section{Abstract}

The primary objective of this study is to apply Aristotle's ethos, pathos, and logos framework to evaluate job interview performance by fresh graduates participating in online interviews during the COVID-19 pandemic (March-May 2020). Data were collected from twenty participants (males 12 and females 8 between 22 and 24 years old) from one of the organisations in Malaysia. The data were analysed qualitatively using NVIVO based on Aristotle's framework. The findings revealed that the selected candidates predominantly used ethos $75 \%$, pathos $40 \%$ and logos $58 \%$ compared to the reserved and the non-selected candidates. Furthermore, the non-selected candidates had poor English language proficiency, persuasive skills, and communication skills. The present study highlights the value of Aristotle's framework for understanding interview presentations, points to the importance of persuasive skills mastery by university graduates, and also informs course designers and practitioners who assist graduating students.

Keywords: Ethos, Pathos, Logos, Fresh Millennial Graduates, Job Interviews

\section{Introduction}

The application of persuasion skills in job interviews adds impact that is crucial to obtaining a second interview or immediate employment (Smith, 2007). Berlanga et al (2013) noted that if the interview is successful and candidates are hired, this shows that the candidates are able to articulate their skills and abilities clearly and convincingly.

However, unemployment has become a world-wide problem more with the COVID-19 pandemic (Zhang, 2020) and university graduates are facing challenges and tough competition to obtain work. Job recruiters are conducting selection interviews online as well as providing orientation training for newly appointed staff. This has led many fresh graduates 
to develop creative methods to promote themselves when searching for suitable employment.

Employers, on the other hand, found several issues among the fresh graduates while conducting interviews. Emanuel et al (2015) noted that many employers seek for candidates who have persuasion skills. In line with Emanuel, Dishman (2016); Ab Rahman et al (2019) posit that most employers look for candidates who can demonstrate persuasion skills as they will be an asset for their organisation.

Consequently, Nicks (2015) highlighted that many of the millennial students are impacted by psychological or societal influences in the decline of their persuasive skills. These are the consequences of the internet revolution and social media, which has reduced the faceto-face communication and interaction. In line with Nicks (2015), Mohamad et al. (2020) found that many millennial fresh graduates have problems using persuasive skills to convince other employees to perform work-related tasks. Kenayathulla et al $(2019$, p. 100) reported that "the millennial fresh graduates are rather poor and unable to converse rationally". This attitude demonstrates that these graduates are poor communicators. Mohamad et al. (2020) further noted that interviewers must feel pleased with the candidates' performance regarding the manner in which they articulate their skills, plans and ideas to add value to the company. Therefore, the current study investigated the rhetorical skills used by fresh graduates in achieving persuasion in job interviews.

\section{Literature Review}

In the succeeding subdivision, the study discusses Aristotle's three artistic proofs, namely, pathos, ethos and logos. Aristotle was the original proponent of the complex relationship between narrators, the meanings they express, and their listeners. He postulated three methods of persuasion, as defined in Table 1. 
TABLE 1. Definitions of Ethos, Pathos and Logos

\begin{tabular}{|c|c|c|}
\hline Types of Persuasion & Definitions & Sample Occurrences \\
\hline Ethos & $\begin{array}{l}\text { Ethos depicts the narrator's } \\
\text { reliability and is embodied by the } \\
\text { personality of the individual } \\
\text { delivering the information } \\
\text { (Demirdogen, 2010). In order to be } \\
\text { successful, the narrator needs to } \\
\text { secure the appreciation of the } \\
\text { listeners (Bronstein, 2013; Holt \& } \\
\text { Macpherson, 2010). There are } \\
\text { suggestions that this can be } \\
\text { accomplished by affirming similar } \\
\text { ideals or events (Duarte. 2010), or } \\
\text { by ascertaining one's skills, ability } \\
\text { or credibility. }\end{array}$ & $\begin{array}{l}\text { "I undertake to send the task } \\
\text { directly to your office on the 9th } \\
\text { of December. Please accept my } \\
\text { apologies for any problems I } \\
\text { caused and thank you for your } \\
\text { kindness." }\end{array}$ \\
\hline Pathos & $\begin{array}{l}\text { When structuring a pathos plea, } \\
\text { Bronstein (2013) proposed that } \\
\text { narrators ought to judge the } \\
\text { listener's sentiments, wishes and } \\
\text { fixed ideas of self. Researchers have } \\
\text { recognised pathos strategies } \\
\text { inclusive of wit (English et al. 2011; } \\
\text { Petty et al. 1976), individual } \\
\text { narratives and sketches (Heath \& } \\
\text { Heath, 2007; Lounsbury \& Glynn } \\
\text { 2001; Scotto di Carlo, 2015b), } \\
\text { colourful language (Bronstein 2013; } \\
\text { Heath \& Heath, 2007) and } \\
\text { constructive reminiscence } \\
\text { (Bronstein 2013). }\end{array}$ & $\begin{array}{l}\text { I underwent surgery and have } \\
\text { to take a week's break at the } \\
\text { hospital. I trust that you would } \\
\text { consider postponing it by a } \\
\text { week. I need to be at the } \\
\text { hospital for about a week after } \\
\text { my surgery for a normal } \\
\text { examination. }\end{array}$ \\
\hline Logos & $\begin{array}{l}\text { Logos refers to expounding a } \\
\text { suitable debate with the } \\
\text { construction, clearness and } \\
\text { reliability of the communication } \\
\text { itself (Holt \& MacPherson 2010; } \\
\text { Scotto di Carlo, 2014a), which is } \\
\text { accomplished by giving accurate } \\
\text { information and focusing on to } \\
\text { sound thinking (English et al. 2011). } \\
\text { Nevertheless, even very reasonable } \\
\text { messages rely upon the listeners for } \\
\text { meaning and their persuasiveness } \\
\text { is dependent on the enthusiasm as } \\
\text { well as capacity of the listeners to } \\
\text { evaluate the information (Petty \& } \\
\text { Cacioppo 1986), and the apparent }\end{array}$ & $\begin{array}{l}\text { Sir, I regret to inform you that } \\
\text { I'm unable to tender my } \\
\text { assignment by the target date } \\
\text { because my younger brother } \\
\text { was gravely ill and was in the } \\
\text { hospital lately. Hence, I had to } \\
\text { care for him and so I was unable } \\
\text { to finish my task in time. }\end{array}$ \\
\hline
\end{tabular}


charisma of the speaker (Chaiken, 1979; Watkins \& Johnston, 2000) or the information itself (Huber, 2016a).

\section{Source: Aristotle's Rhetoric (1954)}

This investigation's theoretical framework is based on Aristotle's perception of rhetoric. Table 1 illustrates his concepts of ethos, pathos and logos with examples from Su-Hie (2018), and the three forms of rhetorical plea are further explained below.

\section{Aristotle's Framework of Persuasion}

The ethos of speakers is related to the awareness of their integrity vis-à-vis the trustworthiness of listeners, forming an important link when interacting (Aristotle, 1954; Higgins \& Walker, 2012; Russell, Perkins \& Grinnell, 2008). In this regard, employers often make decisions regarding the reputation of job candidates based on their current employment status. In addition, casual dress is considered inappropriate for job interviews as interviewers expect an applicant to dress in a way that reflects their professionalism and seriousness about the job (Clark et al., 2010; Fife, 2010; Kuo et al., 2003).

Aristotle defines pathos as the affective or emotional appeals that present persuasive messages to move an audience to action (Aristotle, 1991). Thus, when a reader responds to a writer's emotional appeals, it demonstrates a certain level of intelligence which can lead to persuasion (Fortenbaugh, 1975). An appeal to pathos convinces the audience to respond emotionally and concur to the author's ideas. Therefore, pathos refers to the consequence the message has on the feeling and cognition of the audience.

Logos, which covers appeals to logic and reason, involves the appropriate logical flow of ideas that an individual share in specific situations and as a result, plays an important role in the perception of a person's ethos. Logos is contingent upon the depth of knowledge of the speaker and the methods efficiently used in forming judgments and motives and in demonstrating intelligence (Aristotle, 1954; Gabrielsen \& Christiansen, 2010). It is vital that a speaker demonstrates reliability and candour when in conversation with others while indicating his or her knowledge of the topic under discussion. However, logos can be hampered by disagreements or a lack of adequate knowledge, which may impede the expression of intellectual capacities (Gabrielsen \& Christiansen, 2010; O'Quinn, 2009).

Consequently, the successful use of ethos, pathos and logos in rhetoric depends on the speaker's level of intrapersonal and interpersonal attentiveness as well as adherence to societal conditions (Winn, 2000). For example, a job candidate may apply rhetoric to develop interpersonal relations that create an advantage in gaining employment. Although this is not difficult for some people, familiarity with practical aspects of interactional fluency can add strength to such rhetoric (Saad, Bidin, \& Shabdin, 2017).

\section{Past Studies on Ethos, Pathos and Logos}

Several studies conducted since 2010 have provided insights that form the basis for conducting the current study. Some of these studies hypothesised merging the use of Aristotle's theoretical concepts with various types of media production. Dobbs, et. al., (2015) found compelling strength in the use of pathos in e-business Web designs. In health advertisements, English, at. al., (2011) established that "conventional unconstructive pleas to health could be more effective than constructive pleas while the people could also be 
convinced to accept the concept of healthy living for reasons not exclusively concerned with health per se (to enhance self-esteem)" (p. 277).

In Uysal's (2012) research, 18 Turkish adult native speakers residing in the United States wrote confrontational compositions in Turkish and English. Logos was the most commonly utilised type of rhetorical plea for $72 \%$ of the participants in both the English and Turkish compositions. Furthermore, logos were the main type of plea used in their Turkish compositions (94\%) in contrast to the English compositions (67\%). The study thus revealed that frequent use of this type of rhetorical plea was affected by the language used to write the compositions and may be explained by cultural effects (Kamimura \& Oi, 1998; Okabe, 1983, as cited in Uysal, 2012).

Androniciuc (2016), analysed the subject matter of 77 social media posts in an lohannis election campaign and found that pathos was used extensively by political leaders to garner voter affection in preference to offering points of view or highlighting their stand in campaign discourses. Androniciuc (2016) argued that drawing on persuasion expresses the skill of a campaigner to affect voters' emotions. Arnold (1985) stated that "the utilisation of pathos in persuasive interactions is crucial for peoples' involvement in advertising campaigns, as well as those who generate and apply inducement day today" (p. 26). However, Aristotle's rhetorical pleas were not included in Naksawat, et. al's., (2016) research design, but their study showed that 419 Nigerian scammers manipulated fundamental human feelings in pleas for compassion to trick donors into compliance. These approaches to persuasion relate to effective pleas that Aristotle's theory is categorised as pathos. In contrast, Kagermann, Wahlster, and Helbig (2013) found that Turkish students of English tended not to make overt appeals to emotion in appeal letters compared to native speakers of English. This was explained by the assumption that their appeals could be misinterpreted as making demands.

More recently, Su-Hie (2018) carried out two investigations on ethos, logos and pathos on university students' strategies of persuading their lecturer to grant their request and SuHie and Collin (2017) examined disease risk information in airport posters. These studies examined approaches used by students to influence their lecturers into accepting their arguments. It was found that the students mostly utilised pathos in their reasoning. Samples of writing were collected from 165 English language students in a Malaysian university. They were requested to write their thoughts to convince their lecturer to end class early. The analysis of the writing samples revealed a total of 180 persuasion approaches with only a few students providing more than one approach. The most common persuasion approach was the affection plea (pathos), amounting to more than $50 \%$ of the persuasion approach strategies validated, while the next commonly used approach was the logical plea (logos), and the plea to ethos (credibility) was rarely utilised. The findings further show that students can gain from learning persuasive dialogue to enable them to utilise rhetorical pleas efficiently (Demirdogen, 2010). In comparison to the studies mentioned above, the current study can further enhance and expand knowledge on persuasive email correspondence.

Ting and Collin's (2018) investigations were comparable to Lisa's (2016) research, which concluded that persuasive abilities have to be combined with evaluation expertise. However, ethos, pathos and logos are usually associated with oratory ability and should be carried out along with framing and persuasiveness, as mentioned earlier.

Krishnan, et al., (2020) conducted a study on the use of ethos, pathos and logos by Malaysian engineering students in persuasive email and found that these students preferred expressing emotions to achieve their goals in email writing. This shows the use of persuasion skills based on the situation. 
Therefore, the present study examines the rhetorical pleas discussed above to obtain data on persuasion skills lacking in the research literature as job interviews have not been adequately studied in this regard. Investigations have shown that the rhetoric of persuasion in relation to ethos, pathos and logos can be strategically used by job candidates in employment interviews to influence interviewers (Berlanga et al., 2013). Nevertheless, there is a need to investigate the effects of these types of persuasive rhetoric when used by reserved or rejected candidates in online job interviews.

\section{Framework and Methods}

The framework for the study is drawn from Aristotle'S Rhetorical Theory which concerns itself with the way language is used to persuade target audience successfully. The persuasion in address and dialogue are based on the three types of evidence: Logos (logical reasoning), pathos (human emotions) and ethos (human character). Griffin, (2000) explains that logos relates to factual argument while pathos is related to the feelings or emotions that the speech draws out of the audience, and ethos refers to the manner in which the writer's character or attitude is manifested during the interview. Aristotle's Rhetorical Theory serves as a means to achieving persuasion in discourse. Yang, et al. (2018) used this framework to assess its roles in establishing the trust of customers and indicated three main persuasive variables namely; credibility, emotive bonding and accommodation characteristics to establish the need of honesty between clients and service providers.

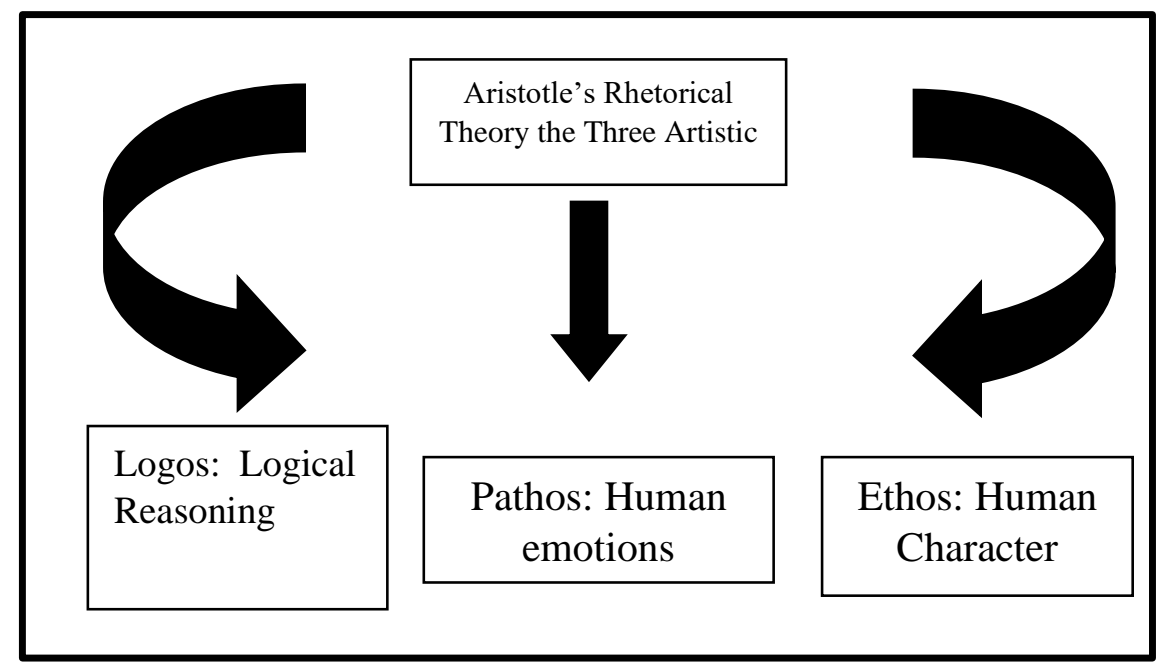

FIGURE 1: Diagrammatical representation of Aristotle's Rhetorical Theory

Hartelius and Browning (2008) also employed rhetorical scholarship to the study of organizations and exhibited that management research conceptualized rhetoric as a theory and an action. They indicated rhetoric as a managerial plan of action for persuading people and as a framework for organizational discourses which highlighted persuasive strategies as managers' most significant actions. The application of Aristotle's Rhetoric to industrial communication was investigated by Murthy and Gosal (2016) who confidently revealed that the use of the three artistic proofs of Aristotle in the language of industrial communication would result in effectiveness of discourse. The current paper contributes to the body of knowledge in rhetoric since it applied the Aristotelian Rhetorical Theory as a framework for analyzing persuasion strategies employed by the fresh graduates during their interviews. 


\section{Methodology}

Setting

The present study obtained conditional consent in carrying out the research. Thirty respondents were shortlisted for the job interviews by the organisation based on their resume. However, only twenty candidates participated in the study due to the ongoing COVID-19 pandemic.

\section{Sampling}

The participants comprised final year students from business and administration programmes who were about to complete their studies. They included twelve males and eight females between 22 and 24 years of age. The interviews were conducted by a senior executive, who had more than 25 years of working experience, especially in job interviews.

Instrument

\section{Google Meet}

The data was collected via Google Meet using standard interview questions by the interviewer. The Google Meet was used due to refrain of contacts of ongoing Pandemic. The questions consisted of self-introduction, strengths and weakness, purpose of hiring and handing problems in workplace.

In-depth-interview

Based on the recorded interviews, the results from the candidates were then triangulated using in-depth interviews with the interviewer via Google Meet. The purpose of the in-depth interview was to analyse how the interviewer determined the selected, reserved and not selected job candidates based on their skills in using ethos, pathos and logos persuasively and effectively.

\section{Data Collection and Analysis Procedures}

The study employed a qualitative method. The recorded data were transcribed and coded using NVIVO version 12 based on definitions of Aristotle's (1954) theory as well as the sample utterances by the study of Su-Hie (2018). Then, the data was analysed based on the theme of "how do you handle problems". This theme has been chosen based on the analysis of the data as well as the emergence of the data as some occurrences were found on the particular question. As Creswell (2018) noted that themes can be chosen for the qualitative analysis based on the analysis and the emergence of the data if it is requited, especially for spoken data.

The data for analaysis were also verified by three post-doctoral students from the human resource management field and three experts from recruitment organisations to ensure that the data were selected accurately and are reliable (Miles et al., 1994). Li (2002) and Wodak (2013) noted that due to the rigorous conditions attached to obtaining authentic data, even one excerpt can contribute significant value to a study. Therefore, only selected excerpts were used for the analysis from the selected, reserved and not selected candidates.

Analysis

The analysis was divided into three categories: selected, reserved and not selected candidates. Table 2 shows the number of occurrences in the use of ethos, pathos and logos from the selected, reserved and not selected candidates. 
INTERNATIONAL JOURNAL OF ACADEMIC RESEARCH IN BUSINESS AND SOCIAL SCIENCES

Vol. 11, No. 8, 2021, E-ISSN: 2222-6990 @ 2021 HRMARS

TABLE 2: Number of Occurrence of Selected, Reserved and Not selected Candidates on the Use of Ethos, Pathos and Logos

\begin{tabular}{llllll}
\hline Candidates & Ethos & Pathos & Logos & $\begin{array}{l}\text { Total } \\
\text { Occurrences }\end{array}$ & $\begin{array}{l}\text { Percentage } \\
\text { (\%) }\end{array}$ \\
\hline Selected & $78(54 \%)$ & $46(40 \%)$ & $45(58 \%)$ & 169 & 50 \\
Reserved & $52(36 \%)$ & $53(46 \%)$ & $21(27 \%)$ & 126 & 37.3 \\
Not Selected & $15(10 \%)$ & $16(14 \%)$ & $12(15 \%)$ & 43 & 12.7 \\
Total Occurrences & 145 & 115 & 78 & 338 & $100 \%$ \\
\hline
\end{tabular}

As shown in Table 2, the results indicate that selected candidates made frequent use of ethos (54.9\%; $n=78)$, pathos $(40 \% ; n=46)$ and logos $(58 \% ; n=45)$ compared to the reserved and not selected candidates. Generally, the selected candidates were more convincing and articulate in persuading the interviewer compared to the reserved and not selected candidates, who had limited knowledge and poor communication skills. The following analysis is based on a sample illustrating the use of ethos, pathos and logos by selected candidates.

\section{Excerpt 1-Ethos}

C1 Sir...well hmm...hmmm for me=for me people are just people I always face different types of customers...I would like to see the situation first certainly I should ...treat customers and using the best method of dealing with problems. Then I will call him/her to calm down or still need my attention as some great customers are looking for attention, sir. Don't you think so?

C2 stress...hmm have a break listen to music

C3 ...by taking a breather once in a while walk away from your work station for 1-2 minutes splashing my face with cold water to keep calm or to wash away the pain go running to distress the body.

C4 what I did was I calmed myself down...I try to seek help from the president and vicepresident to get more members I persuaded many people to join nicely and accepted their rejection calmly

C5 I would say sorry to him and promise him to be better next time...if the pressure inside myself is too high...I would try using various methods to reduce my pressure because work in optimum stress will lead to the highest result of work.

Excerpt 1 shows C1 said, "I would like to see the situation," which shows C1 was concerned about having enough knowledge of the situation to react appropriately. This was followed by the phrase "treat customers and using the best method of dealing with problems," which projected his/her tolerance. The phrase "him/her calm down or still need my attention" reveals his/her patience in facing problems. Next, C2 said she would "have a break listen to music" to calm herself before handling problems. Then, C3 used the phrases "splashing my face with cold water to keep calm" and "to wash away the pain" to show his/her sentimental view about composing himself/herself to have the peace of mind to overcome issues. Meanwhile, C4 used "I calmed myself down," "persuaded many people to join" and "accepted their rejection calmly," which indicated that s/he could manage his/her temper by being attentive. C5 used the phrases "sorry to him and promise him to be better next time," "various of methods to reduce my pressure" and "work in optimum stress will lead to the highest result of work" to depict his/her intelligence in overcoming issues. All these occurrences showed how the selected candidates used their characteristics to be successful in their interviews. 


\section{Excerpt 2-Pathos}

C1 I would like to listen to his/her problem, I would try to make the person calm and make the person in a clear view.

C2 ...listen to the situation carefully and try to put me into his/her position...

C3 I will tell the person that there was one person had the same problem but I resolved the issue. So not to worry as you have come to me.

C4 I will make the person feel safe and comfortable to solve the problem easily.

C5 I would give the person a clear vision to solve the problem and make him/her feel relief.

Excerpt 2 shows C1 used "listen to his/her problem" and "to make the person calm and make the person in a clear view" to show his/her emotional state in being attentive and providing solutions to problems. C2's use of the phrase "listen to the situation carefully and try to put me into his/her position" illustrated empathy as an approach to problem solving. Furthermore, C3 used "tell the person that there was one person had the same problem, but I resolved the issue" to kindly give an explanation to cope with an issue. Furthermore, the phrase "make the person feel safe and comfortable to solve the problem easily," which C4 used, indicated her thoughtfulness and desire to make others feel relaxed. Then, C5 used "give the person a clear vision to solve the problem and make him/her feel relief," which showed generosity in her desire to help others control emotions by offering techniques to overcome problems. These examples indicate the power of emotions used by the selected candidates in the job interviews.

\section{Excerpt 3-Logos}

C1 analyse what the matter is about and pray for strength to overcome ...and for the pressure...face it and try to accomplish the job needed to be done accordingly...then no stress and pressure.

C2 Well...during during those early days of employment I handled stress and pressure by delving into reading...I found great comfort in losing myself in the world of books which created a lifelong habit of reading ....whether it is fiction or non-fiction the newspaper the news online on the internet...etc...yes

C3 Sir...well hmm...hmmm for me people are just people I always face different types of customers...I would like to see the situation first certainly I should ...treat customers and using the best method of dealing with problems. Then I will call him/her calm down or still need my attention as some great customers are looking for attention, sir. Don't you think so?

C4 (laughs) to me (.) the key will be personal time management...for example, stress may come due to the need to beat the dateline...thus (.) I will try my best to avoid stress and pressure by ensuring that I plan and prioritise a task before reaching the dateline...having another backup plan in term of a sudden change of plan is also important (.)to prevent me another word early preparation is how one can avoid stress and pressure.

C5 Usually, I talk to friends and asking their opinions...about certain problems or stress or pressure or it can open up your purview on the subject or...leading to some solution meanwhile I take up sports to release my stress...yes yes, it is also bringing good health to me.

Excerpt 3 shows the phrases "analyse what the matter is about and pray for strength 
to overcome" and "face it and try to accomplish the job needed to be done accordingly" used by $\mathrm{C} 1$, which depict the rationality of the candidate when solving problems. Next, C2 used "delving into reading," which showed his/her analytical thinking in positively resolving issues. Similarly, the lines "I would like to see the situation first," "treat customers and using the best method of dealing with problems" and "call him/her to calm down or still need my attention as some great customers are looking for attention" used by C3 illustrates his/her her critical thinking skills in solving problems. Moreover, the phrases "personal time management," "by ensuring that I plan and prioritise a task before reaching the dateline," "having another backup plan in case of a sudden change of plan is also important" and "early preparation" proved that C4 was able to anticipate and solve issues correctly. Furthermore, "talk to friends and asking their opinions" and "take up sports" shows that C5 was open-minded and thought critically before taking any action. All these actions depicted how the candidates handled their problems by thinking analytically as well as showing a sensible attitude to the interviewer. Therefore, these characteristics of the candidates helped to make them suitable choices for employment.

Precise examples of ethos, pathos and logos were found in the data set. The selected candidates conversed articulately to convince the interviewer. Excerpts 1, 2 and 3, "I prefer to observe the conditions first" (ethos), "observe the conditions cautiously and attempt to place myself into his/her situation" (pathos), and "examine what the problem and plead for the drive to surmount" (logos) are examples of candidates using persuasion skills to influence the interviewer into selecting them for employment. They also demonstrated good English language proficiency as portrayed in their communication skills.

\section{Reserved}

\section{Excerpt 4-Ethos}

C6 Like me, I always listen to songs. I think it is a good way to resolve.

C7 Sir for me the best is just listen to them listen and then easy to handle them trust me, sir...

C8 Well, the major challenges will be to organise well the classroom and make the students learn eagerly the lessons well and... ensure they can read listen to speak write enormously well in their English... so that they can perform well in society in their respective field.

C9 I would prefer to do house chores to overcome my stress...

C10 For me...the best solution is to ask others opinions and make a better decision to settle down my problem.

Excerpt 4 shows the use of ethos by Candidates 6-10. The phrase "always listen to songs" used by C6 was not a clear answer, and the candidate did not manage to depict his/her character appropriately. This is followed by the line where C7 used "just listen to them listen and then easy to handle them," which partially explained his/her attitude toward dealing with problems. Meanwhile, the expressions used by $\mathrm{C} 8$, "make the students learn eagerly the lessons well," "ensure they can read," "listen," "speak" and "write enormously well in their English," indicated that the candidate was not clear in explaining how to resolve issues. Then, C9 used the phrase "do house chores," which was not an adequate explanation of how to resolve the problem posed by the interviewer. This was followed by C10's use of the phrase "to ask other's opinions and make a better decision to settle down," which did not clearly explain his/her way of handling problems. These examples show that the candidates' poor communication skills resulted in poor articulation. Therefore, the interviewer categorised 
them as reserved.

\section{Excerpt 5-Pathos}

C6 I will readjust my attitude toward the person not too defensive.

C7 Attempt to move the confrontation to a private place to avoid complications.

C8 I will think...and find a solution.

C9 I will put myself in it...and solve the problem.

C10 I will make myself clear and relief my stress.

Excerpt 5 shows $\mathrm{C} 6$ used "readjust my attitude toward the person not too defensive," which showed an inability to express information clearly. Next, C7's phrase "attempt to move the confrontation to a private place to avoid complications" was not consistent with the interviewer's question on problem solving. Also, the phrase "think...and find a solution" used by $\mathrm{C} 8$ was not transparent and gave a poor impression of her/himself to the interviewer. Furthermore, C9's expression "put me in it and solve the problem" did not show how to handle the problem. Moreover, C10's use of "make myself clear and relief my stress" gave a poor impression to the interviewer. These occurrences show the key reasons why Candidates 6 to 10 were categorised as reserved.

\section{Excerpt 6-Logos}

C6 I would prefer to play games with my friends to release my stress...

C7 It better for me to handle my problems by asking opinions from my parents.

C8 I will go to the cinema to overcome my stress by watching my favourite movie.

C9 I will look at some counselling programmes to handle my problems.

C10 I will fix my problems by confiding with my friends.

In Excerpt 6, C6's phrase "play games with my friends to release my stress" was not elaborated further by the candidate due to his/her stress. Furthermore, C7's phrase "asking opinions from my parents" did not indicate her ability to handle problems. Next, the line used by C8 "go to the cinema to overcome my stress by watching my favourite movie" was not rationally articulated to the interviewer. Then, C9's explanation "look to some counselling programs to handle my problems" was not strongly supported with evidence. Also, the line "fix my problems by confiding with my friends" revealed that C10 was not able to cope with problems. All these occurrences prove that poor communication abilities lead to poor persuasive skills.

Excerpts 4, 5 and 6 reveal that reserved candidates provided doubtful answers and generally did not display confidence in their interviews. Also, their abilities to articulate ideas were insufficient to constructively present information. The responses to questions by the reserved candidates were not persuasive enough because of poor communication skills. Thus, they failed to influence the interviewer positively. The examples mentioned above confirm that poor interactive abilities hamper persuasive abilities. This result corroborates the findings of previous research by Mohamad et al. (2020), which evaluated these abilities in job interviews as essential and crucial in determining a candidate's employability.

\section{Not Selected}

\section{Excerpt 7-Ethos}

C11 I'm out of the classroom (.) I will leave everything behind...so I can deal with them quite well. 
C12 I always manage stress by listening to the music and...yaar it works.

C13 (Laughs) stress...pressure...we...I would prefer to work under control and the kind of work pressure or stress...I can manage I guess...yes, I can.

C14 I can control it by walking in the garden.

C15 I would prefer to cook several foods.

In Excerpt 7, C11's statements "I'm out of the classroom" and "I will leave everything behind" did not convincingly explain how s/he handled problems. Then, C12's reply "listening to the music" did not show his/her nature in coping with the issues. Furthermore, C13's "prefer to work under control" depicted that $s /$ he was not capable of handling stress. Meanwhile, C14 used "walking in the garden," which was an inappropriate response on how to solve the matter. Next, "cook several foods" by C15 was not a clear indication of how to handle the problems posed. All these occurrences illustrate that poor communication skills led to the candidates' failure in the job interview.

\section{Excerpt 8-Pathos}

C11 I am the person to understand and control them not to be angry.

C12 I will tell don't feel frustrated. I am here to help you.

C13 I will focus and keep calm the person.

C14 I will make the person feel comfortable.

C15 I will make the person passionate.

In Excerpt 8, C11's phrase "the person to understand and control them not to be angry" did not show a clear mind for handling the problem. This was followed by phrases used by C12 like "tell don't feel frustrated" and "I am here to help you," which were not adequately detailed explanations of how to cope with a problem and hinted at his/her weakness. Next, C13's phrase "focus and keep calm the person" was not persuasive enough to solve the problem. Then, C14 used "make the person feel comfortable," which was an inappropriate elaboration as well as revealing poor emotions to the interviewer. However, C15's statement "make the person passionate" indicated that the candidate was unable to provide a clear answer due to his/her emotion. Uttering inconsistent answers and having a lack of persuasive skills were the reasons why these candidates failed to get through the interview.

\section{Excerpt 9-Logos}

C11 I will go to the cinema...

C12 I will just go to play some outdoor games...

C13 ...For me...I will share my problems with my family members...

C14 I will text my friends...

C15 I will stay out with my friends...

In Excerpt 9, C11's phrase "go to the cinema" did not clearly express how to handle the problem. Then, "play some outdoor games" uttered by $\mathrm{C} 12$ failed to provide a decisive answer on coping with his/her issue. Meanwhile, the phrase C13 used, "share my problems with my family members," was not well enough supported to show a clear decision on solving the problem. Next, C14 used "text my friends," which was not expressed critically to cope with the problem. After that, C15's statement "stay out with my friends" was not elaborated logically in how to solve the issue. These are occurrences where candidates were not selected in the job interviews due to unimpressive and illogical answers.

Excerpts 7, 8 and 9 show that the not selected candidates faced difficulties in 
answering questions effectively and also exhibited an inability to solve issues. The not selected candidates showed that they were also unable to handle stressful situations and arrive at concrete decisions in the workplace. The inability to interact well was due to poor communicative ability that greatly impeded their presentation. The performance of the not selected candidates showed a poor grasp of generic employment skills, and that led to their desultory performance in the interviews, and subsequently, they were non-selections for employment.

The next section of the analysis was on the in-depth interview with the interviewer. In line with the above findings, the interviewer mentioned that the selected candidates;

'... were able to use the ethos, pathos and logos appropriately as their communication skills are favourable due to English languages proficiency...'

'...they were able to use ethos, pathos and logos at the moderate level but better than reserved and not selected...'

'... the organisation needs people who can communicate well and as the nature of work requires good communication skills...'

'...we need people to talk convincingly and respect other staff's opination especially in the meeting...'

'...ethos, pathos and logos play an important role in a job interview and ease the hiring process...'

'...the selected candidates were also able to show their maturity in answering their questions...'

'...the selected candidates were able to think and relate their answers what they went through even though they did not have working experience...'

The findings show that the interviewer was impressed with the selected candidates use of persuasion skills. The use of persuasion skills portrayed competent communication ability due to their good English language proficiency. Furthermore, the interviewer mentioned that the use of persuasion skills in job interviews was important. Based on this, the findings show a similarity with Ting's (2018) results, namely, even though they were students without exposure to external factors, they could use their maturity in portraying their sensibility in the interaction, which was crucial in the job interviews.

Pertinent to reserved candidates, the interviewer mentioned that:

'...the reserved candidates were able to speak but not convincing...'

'...they are very poor in communication skills therefore; persuasion skills were not able to demonstrate...'

'...sometimes the use of word and phrases portrays their poor English language proficiency, thus reserved candidates were not able to use the persuasion skills appropriately...'

It was found that the reserved candidates were unable to utter appropriate words and phrases, which indicated poor English language proficiency. As a result, the reserved candidates were not able to interact convincingly. Therefore, their use of ethos, pathos and logos was not as appealing as that of the selected candidates. This finding is in consensus with Ab Rahman et al.'s (2019) that employers sought candidates who could interact with the staff in professional interactions.

As for the not selected candidates, the interviewer pointed out that;

'...of course, the not selected candidates interact but I am sad with the choice of words does not reflect their capabilities to hire them...' 
'...the use of persuasion skills was not convincing at all...'

'...they should sharpen their English language proficiency which leads to good communication skills and they can use the persuasion skills in a good manner...'

From the interviewer, it was found that reserved candidates were not able to interact well due to poor proficiency. Hence, their use of ethos, pathos and logos was not impressive. Similarly, the findings conform with the study of Kenayathulla et al. (2019) who found that employers look for candidates that interact in good English language and have the ability to carry out decent interactions. In general, it is suggested that job applicants should be prepared, and educational institutions should play an important role in preparing students for job interviews.

\section{Discussion}

The respondents of this study can be categorized into three groups that are successful candidates, candidates in reserve and failed candidates. The use of ethos, pathos and logos strategies successfully distinguished the three types of interview candidates. Overall the ethos, pathos and logos strategies have been used by successful candidates in their communication skills as well as persuasive methods to solve an issue or problem highlighted during the interview session.

Although successful candidates used all three of these strategies but there are differences in the frequency of using them. In this study, logos is a strategy that is most often used by successful candidates in the interview which is 58\% (among the many compared to ethos and logos). Pathos is the least used by successful candidates, this is due to the Asian culture which is more emotional when communicating with higher ranking officers. This is very accurate when compared to the findings recommended by Uysal (2012), that is, the way we communicate is influenced by cultural factors. However, compared to previous studies such as Su-Hie and Collin (2017) the most widely used strategy for persuasion is pathos. This is due to awareness of their integrity, professionalism and seriousness about the employability in the Malaysian context.

Reserved candidates, on the other hand, show that their ability to use the ethos, pathos and logos strategies is on a moderate level. Interviewers were less confident with these candidates because their communication skills are only satisfactory compared to the candidates who have been selected. This finding is consistent with Dobbs, Koller, and Ramaswamy's (2015) that persuasion skills determine a speaker's capabilities, as in job interviews. Furthermore, the weakness in this persuasive strategy is actually the impact of poor interactive abilities that hinder persuasive abilities. This result corroborates the findings of previous research by Mohamad et al. (2020) who evaluated these abilities in job interviews as essential and crucial in determining a candidate's employability. So, it is precise with the findings of this study that the ethos, pathos and logos strategies to assess the strengths and weaknesses of the interview candidates are accurate.

Basically, candidates who fail in interviews are due to poor communication skills and were not able to deliver a good presentation in the interview session. The performance of the not-selected candidates showed a poor grasp of generic employment skills, and that led to their desultory performance in the interviews, and subsequently, they were non-selected for employment. Failing to use the ethos, pathos and logos strategies as stated by Winn (2000) ultimately led to them being unsuccessful in the interview. 
The conclusions drawn from this investigation on rhetorical pleas in job interviews reveals two issues for further discussion. The first is that potential employers, when deciding to hire, seek candidates who have valuable abilities and knowledge and who possesses good behavioural traits. The second is acknowledgment of the constantly evolving communication environment and the rising numbers of new graduates seeking jobs. This study provides insight into the employment problems faced by new graduates, especially in their job interviews. As such, utilising the ethos, pathos and logos strategies of persuasion as analytical tools would provide interviewers with a clearer comprehension of persuasion skills. Furthermore, rhetorical pleas are utilised to effect persuasion not merely in political speeches but in more mundane activities like job interviews, as well. When new graduates were requested to reply on how they "manage issues, problems and pressure" the candidates applied Aristotle's rhetorical pleas, thus extensively using persuasive skills.

Nevertheless, to attain success in job interviews, candidates need not limit themselves to rational thinking, but the reserved and unselected candidates applied logic inappropriately owing to their lack of interactive experience. Therefore, the reserved and unselected candidates failed to persuade the interviewers to select them.

However, a few candidates could apply the three persuasive skills, hoping to convince the interviewer, so they were selected. Nevertheless, the lack of communication skills made it difficult for the reserved and unselected candidates to apply persuasive skills effectively. Moreover, the literature on persuasive discussion has revealed that rhetorical pleas are regularly applied in combination even though one form may prevail, such as pathos in advertisements (Nair \& Ndubisi, 2015; Winn, 2000), political discussion (Androniciuc, 2016; Mori, 2016) and social media interactions (Emanuel et al., 2015; Fife, 2010). Al-Momani (2006) stated that a combination of pleas might result in better outcomes for millennial fresh graduates, but this inference requires verification in further investigations on job interviews.

\section{Implications of the Study}

All the three, logos, ethos and pathos persuasive appeals of Aristotle's are equally vital especially where language is used because of its versatility regardless of the discipline. During interviews it is significant for the candidate to employ persuasive appeals to strategically amplify one's strength to convince the employer that he/she will be an asset to the organization to secure a job. If the interviewee uses the rhetorical appeals aptly, it would create an effective impact on the interviewer. Additionally, the ability in using Aristotle's persuasive appeals would impress the employer or interviewer to develop a credibility over the interviewee to yield positive results at the interview. Undeniably, the classical Aristotelian rhetoric should be laid-off by the interviewee but maximized the impact. The job interviews are a ubiquitous phenomenon where Aristotle's ancient literary tool is still applicable in our modern times.

\section{Conclusion}

In this investigation, the aim was to assess the use of ethos, pathos and logos in job interviews among millennial fresh graduates. This study has shown that online interviews present a means to overcome various questions generally confronted by job seekers, as mentioned earlier regarding the COVID-19 pandemic. The use of ethos, pathos and logos could offer the prospect of engaging with the interviewers through emotional pleas and highlight this usage at the initial stage of the job interviews, thereby benefiting both interviewers and candidates. Nevertheless, it cannot be discounted that there are both 
superficial and actual gains as well as drawbacks for fresh candidates when attending online interviews.

The utilization of ethos, pathos and logos can offer a precise means of expressing vital information regarding a candidate that can support their employment process. Furthermore, the findings of the present study indicate that the usage of ethos, pathos and logos in online interviews will probably produce constructive outcomes for the candidates. It provides correlative information about the candidate that is not likely to be extracted from résumés, curriculam vitae and profiles. Additionally, this shows the candidate's characteristics, like honesty and personality, and also reveals the interactive skills of the candidate by way of introspective and well-actualised use of ethos, pathos and logos, including spoken and visual information that are included in the interviewer's expectations.

\section{References}

Ab Rahman, F., Mohamed, A. H., Saidin, K., \& Ahmad, N. S. (2019). Exploring perceptions of employers on communication skills among fresh graduates. Practitioner Research, 1(2),69-85. http://e-journal.uum.edu.my/index.php/pr/article/view/8192

Ab Rashid, R., Jamal, S. N., Ibrahim, N. S. N., Yunus, K., Azmi, N. J., Anas, M., \& Mohamed, S. B. (2016). Rhetoric and health: How fitness trainers persuade public on social networking site. Man In India, 96(11), 4673-4679. https://www.researchgate.net/publication/311743138

Alex, T. (2011). The student perspective on employability. Journal Studies in Higher Education, 38(6) 841-856. https://doi.org/10.1080/03075079.2011.604408

Al-Momani, K. R. (2014). Strategies of persuasion in letters of complaint in academic context:

The case of Jordanian university students' complaints. Discourse Studies, 16(6), 705728. https://journals.sagepub.com/doi/abs/10.1177/1461445614546257

Androniciuc, A. I. (2016). Using social media in political campaigns: Evidence from Romania. Practical Application of Science, 4(1), 23-39. https://ideas.repec.org/a/cmj/seapas/y2016i10p51-57.html

Arnold, V. D. (1985). The importance of pathos in persuasive appeals. Bulletin of the Association for Business Communication, 48(4), 26-27. https://journals.sagepub.com/doi/abs/10.1177/108056998504800409

Aristotle. (1954). The rhetoric and the poetics of Aristotle (W. R. Roberts \& I. Bywater, Trans.). New York: Modern Library.

Berlanga, I., García-García, F. \& Victoria, J. S. (2013). Ethos, pathos and logos in Facebook. User networking: New rhetoric of the 21st century. Scientific Journal of Media Education, 41(21), 127-135. https://www.academia.edu/4424061/Ethos_pathos_logos

Bovee, C. L. \& Arens, W. F. (1992). Contemporary Advertising. Irwin.

Clifton, J., \& Van De Mieroop, D. (2010). 'Doing' ethos: A discursive approach to the strategic deployment and negation of identities in meetings. Journal of Pragmatics, 42(1), 2446. https://www.researchgate.net/publication/248451705_-

Clark, A. M., Anderson, R. C., Kuo, L. J, Kim, I. H., Archodidou, A. \& Nguyen-Jahiel, K. (2003). Collaborative reasoning: Expanding ways for children to talk and think in school. Educational Psychology Review, 15(2), 181-198. https://link.springer.com/article/10.1023/A:1023429215151

Creswell, J. (2018). Research design: qualitative, quantitative, and mixed methods approaches (5th ed.) London, UK: SAGE Publications. 
Demirdugen, U. D. (2010). The roots of research in (political) persuasion: Ethos, pathos, logos and the Yale studies of persuasive communications. International Journal of Social Inquiry, 3(1), 189-201. https://www.semanticscholar.org/paper/The-Roots-ofResearch-in-(political)-Persuasion

Dishman, L. (2016). These are the biggest skills that new graduates lack. Fast company. https:// www.fastcompany.com/3059940/these-arethe-biggest- 'skills-that-newgraduates-lack

Dobbs, R., Koller, T., \& Ramaswamy, S. (2015). The future and how to survive it. Harvard Business. https://hbr.org/2015/10/thefuture-and-how-to-survive-it

English, K. S., Sweetser, K. D., \& Ancu, M. (2011). YouTube - incaution of political talk: An examination of persuasion appeals in viral video, American Behavioral Scientist, 55(6), 733-48. https://doi.org/10.1177/0002764211398090

Emanuel, B., Rodrigues, C. \& Martins, M. (2015, August). Rhetoric of interaction: analysis of pathos. in international conference of design, user experience, and usability (pp. 417427).

Springer International Publishing. https://www.academia.edu/18235724/Rhetoric_of_Interaction_Analysis_of_Pathos

Fife, J. M. (2010). Using Facebook to Teach Rhetorical Analysis. Pedagogy,10(3), 555-562. https://digitalcommons.wku.edu/cgi/viewcontent.cgi?article=1002\&context=english_f ac_pub

Gabrielsen, J., \& Christiansen, T. J. (2010). The Power of Speech. Denmark: Gyldendal.

Green, J. (2009). Qualitative methods for health research (2nd ed.). Thousand Oaks, CA: Sage.

Higgins, C., \& Walker, R. (2012). Ethos, logos, pathos: strategies of persuasion in social/environmental reports. Accounting Forum, 36, 194-208. https://www.sciencedirect.com/science/article/pii/S0155998212000178

Horovitz, B.( 2012). After Gen X, Millennial, what should next generation be. USA Today. https://www.kasasa.com/articles/generations/gen-x-gen-y-gen-z

Jennifer, L. L., \& Jorge, V. (2018). Affective Effects of Offering Options on Persuasiveness of Fear Appeals, Journal of Promotion Management, 0, (0).1-15. https://www.tandfonline.com/doi/abs/10.1080/10496491.2018.1427650

Kagermann, H., Wahlster, W., \& Helbig, J. (2013): Recommendations for implementing the strategic initiative Industry 4.0 (Eds.), Final report of the industry 4.0 Working Group.

Kenayathulla, H. B., Ahmad, N. A., \& Idris, A. R. (2019). Gaps between competence and importance of employability skills: Evidence from Malaysia. Higher Education Evaluation and Development, 13(2) 97-112. https://www.emerald.com/insight/content/doi/10.1108/HEED-08-20190039/full/html

Krishnan, I. A., Teoh, M. L., Hee, S. C., Ramalingam, S., \& Maruthai, E. (2020). Using rhetorical approach of ethos, pathos and logos by Malaysian engineering students in persuasive email writings. Malaysian Journal of Social Sciences and Humanities (MJSSH), 5(4)19-33. https://msocialsciences.com/index.php/mjssh/article/view/386

Li, W. (2002). What do you want me to say?' On the conversation analysis approach to bilingual interaction. Language Teaching, 31(1), 02-28. https://www.academia.edu/1171724/

Li, R., Suleiman, R. R. R., \& Sazalie, A. (2015). An investigation into Chinese EFL Learners' Pragmatic Competence. GEMA Online ${ }^{\circledR}$ Journal of Language Studies, 15 (2), 101-118. 
http://ejournal.ukm.my/gema/article/view/8661

Lisa, L. (2016). Stunning statistics for persuasive speaking. Communication Teacher, 1740-4630. http://dx.doi.org/10.1080/17404622.2016.1244346.

Miles, M. B., \& Huberman, A. M. (1995). Qualitative data analysis: An expanded sourcebook (2nd Eds.). Sage Publications.

Mori, K. (2016). Analysis of the discourse of diplomatic conflict at the UN: Application of ethos, pathos, logos. Proceedings of 12th International Conference on Humanities \& Social Sciences 2016 (IC-HUSO 2016), Faculty of Humanities and Social Sciences, Khon Kaen University, Thailand. https://www.researchgate.net/publication/32340032

Naksawat, C., Akkakoson, S., \& Loi, C. K. (2016). Persuasion Strategies: Negative Forces in Scam E-mails. GEMA Online ${ }^{\circledR}$ Journal of Language Studies, 16(1), 1-7. http://ejournal.ukm.my/gema/article/view/10325

Nair, S. R., \& Ndubisi, N. O. (2013). Entrepreneurial Values, Environmental Marketing and Customer Satisfaction: Conceptualization and Propositions. Enterprise Development in SMEs and Entrepreneurial Firms: Dynamic Processes. 257-269. https://www.igiglobal.com/chapter/entrepreneurial-values-environmental-marketing-and-customersatisfaction/122972

Nicks, D. (2015). Hotels Airbnb competition report. Times Magazine. http://time.com/ money/4117068/hotels-airbnb-competition-report/.

O'Quinn, K. (2009). The elements of persuasion: Three principles that will strengthen any appeal. Public Relations Tactics, 16(2), 20-32.

http://connection.ebscohost.com/c/articles/36665244/elements-persuasion-threeprinciples-that-will-strengthen-any-appeal

Russell, B., Perkins, J., \& Grinnell, H. (2008). Interviewees' overuse of the word "like" and hesitations: Effects on simulated hiring decisions. Psychological Reports, 102,111-118. https://journals.sagepub.com/doi/abs/10.2466/pr0.102.1.111-118

Saad, N., Bidin, S. J., \& Shabdin, A. A. (2017). Refusal Strategies Used by Malay ESL Students and English Native Speakers to Refuse a Request. Proceedings of the ICECRS, 1(1), 2338. https://doi.org/10.21070/picecrs.v1i1.609

Sabrena, R. P., Susan, A. S., Lawrence, A. H., \& Jeff, L. (2013). Employment interview outcomes and speech style effects. Journal of Language and Social Psychology, 21(2), 144-161. https://journals.sagepub.com/doi/10.1177/02627X02021002003

Smith, V. (2007) Aristotle's classical enthymeme and the visual argumentation of the twenty-first century, Argumentation and Advocacy, 34(3) 4, 114-23. https://www.tandfonline.com/doi/abs/10.1080/00028533.2007.11821667

Su-Hie, T. (2018). Ethos, logos and pathos in university students' informal requests. GEMA Online ${ }^{\circledR}$ Journal of Language Studies, 18(1), 234-251. http://ejournal.ukm.my/gema/article/view/23387

Su-Hie, T., \& Collin, J. (2017). Framing of disease risk messages in airport banners. International Journal of Law Government and Communication, 2(6),63-75.http://www.myjurnal.my/public/article-view.php?id=124497

Uysal, H. H. (2012). Argumentation Across L1 and L2 Writing: Exploring Cultural Influences and Transfer Issues. Vigo International Journal of Applied Linguistics, 9(2),133159. https://www.sciencedirect.com/science/article/pii/S187704281402597X

Winn, W. (2000). The persuasive power of pathos in e-commerce web design: A new area for research. In Professional Communication Conference, 2000. Proceedings of 2000 
INTERNATIONAL JOURNAL OF ACADEMIC RESEARCH IN BUSINESS AND SOCIAL SCIENCES

Vol. 11, No. 8, 2021, E-ISSN: 2222-6990 @ 2021 HRMARS

Joint IEEE International and 18th Annual Conference on Computer Documentation (IPCC/SIGDOC 2000), (pp. 155-160). IEEE.

https://dl.acm.org/doi/10.5555/504800.504824

Wodak, R. (2013). Critical discourse analysis. London, UK; Sage.

Zhang, L. (2020). COVID-19 leads to dramatic unemployment, young people suffer the most. https://news.cgtn.com/news/2020-05-29/COVID-19-leads-to-dramaticunemployment-young-people-suffer-the-most-QSUcPNPJOQ/index.html 